\title{
MULTIPLE INTRACRANIAL SCHWANNOMAS: CASE REPORT
}

\author{
Mario Mihalj ${ }^{1}$, Krešimir Dolić ${ }^{2}$, Pavao Jurinović ${ }^{1}$, Nikolina Ivica Miše ${ }^{1}$, \\ Marina Titlić ${ }^{1}$ and Irena Pintarić ${ }^{1}$ \\ ${ }^{1}$ Clinical Department of Neurology, ${ }^{2}$ Clinical Department of Diagnostic and Interventional Radiology, \\ Split University Hospital Center, Split, Croatia
}

\begin{abstract}
SUMMARY - Schwannomas are benign encapsulated tumors arising from the sheaths of peripheral nerves. They present as slowly enlarging solitary lumps, which may cause neurological defects. Multiple schwannomas in non-neurofibromatosis type 2 patients are extremely rare. We report a case of a 60-year-old female patient, without any family history of neurofibromatosis or schwannomatosis, presented with trigeminal neuralgia and progressive facial nerve palsy. Magnetic resonance imaging revealed the presence of acoustic schwannoma involving facial nerve and trigeminal schwannoma of the cisternal part of the nerve involving gasserian ganglion (Meckel's cave). After gamma knife radiosurgery, trigeminal neuralgia was relieved completely with improvement of facial nerve palsy.
\end{abstract}

Key words: Neurilemmoma - diagnosis; Neurilemmoma - surgery; Neuroma, acoustic - diagnosis; Neuroma, acoustic - surgery; Trigeminal nerve diseases - surgery; Case reports

\section{Introduction}

Schwannomas (neurilemmomas) are benign, slowgrowing, encapsulated tumors originating from Schwann cells that form myelin sheath around peripheral, cranial, and autonomic nervous systems. They develop on the outside of the nerve, but may push it aside or against adjacent structures causing damage ${ }^{1}$. Schwannomas account for $7 \%$ of all intracranial tumors ${ }^{2}$, and among them vestibular schwannomas are most common. However, those originating from the trigeminal ganglion or nerve root, or other cranial nerves are considered rare ${ }^{1}$.

We report a case of schwannomas of the vestibular and trigeminal nerves in a non-neurofibromatosis type 2 (NF2) female patient who presented with trigeminal neuralgia and progressive facial nerve palsy.

Correspondence to: Nikolina Ivica Miše, MD, Clinical Department of Neurology, Split University Hospital Center, Spinčićeva 1, HR-21000 Split, Croatia

E-mail: n_ivica@net.hr

Received February 5, 2014, accepted March 1, 2016

\section{Case Report}

A 60-year-old female was admitted to the Clinical Department of Neurology, Split University Hospital Center, because of acute right-side facial palsy (HouseBrackmann grade IV). She did not complain of any episode of vertigo, dizziness, or tinnitus. The basic laboratory tests (peripheral blood and blood chemistry findings) were within the normal limits.

Her medical history showed that she also had suffered from right-sided infranuclear facial palsy (House-Brackmann grade III) a year before. Otherwise, she was healthy and no other focal neurological signs or symptoms including hearing disturbances were elicited at that time. She was administered $20 \mathrm{mg}$ prednisone per day for 5 days, including gastric and local eye protection therapy. Prednisone was discontinued by gradual reduction of dosage. After physiotherapy, facial function improved gradually to grade II. Six months later, she presented with right trigeminal neuralgia. The pain affected initially the maxillary and then the ophthalmic divisions of the trigeminal nerve, characterized as sharp and lancinating pain of moder- 


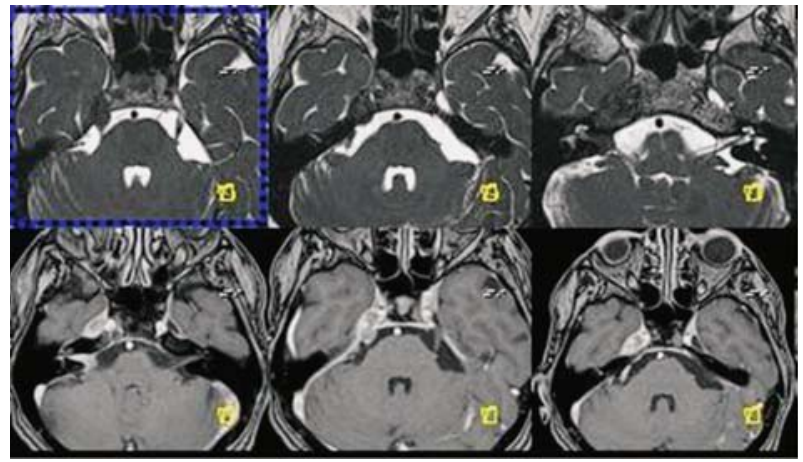

Fig. 1. Magnetic resonance imaging showing vestibular schwannoma of the internal auditory canal and trigeminal schwannoma of the cisternal part of the nerve involving gasserian ganglion (Meckel's cave).

ate to severe intensity. Systemic and neurological examinations were normal. In particular, trigeminal sensation was intact bilaterally and trigeminal reflexes were normal. Conventional analgesia in high dosage relieved pain. Based on her positive medical history of neuralgia, magnetic resonance imaging (MRI) of the brain was performed to reveal the presence of rightside trigeminal and vestibular nerve schwannomas also involving the ganglion segment of the facial nerve (Fig. 1).

Ophthalmologic and general physical examinations did not reveal any findings suggestive of neurofibromatosis. There was no family history of neurologic disturbances, café-au-lait spots, tumors of the skin or central nervous system.

The patient underwent gamma knife radiosurgery for trigeminal schwannoma and vestibular schwannoma. An obvious decrease in tumor volumes was observed. Trigeminal neuralgia was relieved completely with improvement of facial nerve palsy (House-Brackmann grade II) during 9-month clinical follow up.

\section{Discussion}

Vestibular schwannomas are the most common intracranial site of schwannoma occurrence. They comprise $90 \%$ of all cranial nerve schwannomas, followed by the second most common but much rarer trigeminal schwannomas ${ }^{1}$.

Cranial nerve schwannomas usually manifest sporadically as a single neoplasm. The presence of multiple schwannomas in the same patient suggests tumorigen- esis and a possible association with NF2 or schwannomatosis ${ }^{3,4}$. Only $3 \%$ of the schwannoma patients have multiple schwannomas in association with NF2, and $2 \%$ have schwannomatosis without NF2 ${ }^{4}$.

The National Institutes of Health criteria ${ }^{5}$ are probably the most reliable diagnostic criteria for NF2. These criteria have been expanded ${ }^{6}$ to also include patients with unilateral acoustic schwanoma, and two of the following: meningioma, glioma, neurofibroma, schwannoma, or posterior subcapsular lenticular opacity. Our patient did not fulfill diagnostic criteria for NF2. Except for those two schwannomas, she did not reveal any other findings suggestive of NF2, and what is also important for diagnosis, her family history was negative for neurofibromatosis.

Schwannomatosis is the third major form of neurofibromatosis. Geneticists, neurologists, and pathologists have recognized that schwannomatosis is distinct from NF2. It is characterized by the presence of two or more non-intradermal schwannomas, including no bilateral vestibular schwannomas. Some schwannomatosis patients have been reported to have unilateral vestibular schwannoma ${ }^{7}$. According to these criteria, our patient could probably be classified under this diagnosis.

Kambe et al. ${ }^{8}$ report on the same case of multiple schwannomas in a non-NF2 patient. The patient, without any family history of neurofibromatosis, presented with two separate schwannomas, trigeminal schwannoma and vestibular schwannoma. Like our patient, this patient did not reveal any other findings suggestive of NF2 either, but molecular genetic analysis detected genetic alterations of the NF2 gene.

It is not always easy, on the basis of the clinical picture, to classify patients as NF2 or schwannomatosis, especially those patients with unilateral vestibular schwannoma. However, according to Aghi et al., who have described clinical features of unique phenotypeunilateral vestibular schwannoma with other NF2-related tumors, patients with this phenotype should undergo evaluation and monitoring similar to that conducted in patients with NF2, and the possibility of aggressive contralateral vestibular schwannoma formation should also be considered in their clinical evaluation?

Following the diagnosis, and taking into account the patient's age and locations of tumors, gamma knife radiosurgery was considered therapy of choice in the present case. Long-term follow up demonstrated gamma knife radiosurgery to offer a high rate of tumor 
control, preservation of multiple nerve functions, and good quality of life in patients with both vestibular schwannoma and trigeminal schwannoma ${ }^{10,11}$.

The presented case is unique because it shows a rare phenotype of multiple schwannomas (unilateral vestibular schwannoma and trigeminal schwannoma) in a non-NF2 patient with no other stigmata of neurofibromatosis.

It also shows that progressive facial palsy without any disturbances of hearing is probably not Bell's palsy. In patients with such symptoms, especially if they have recurrent facial palsy and other neurological signs, it is important to examine other rare causes.

\section{References}

1. Woodruff JM, Kourea HP, Louis DR, Scheithauer BW. Schwannoma. In: Kleihues P, Cavenee WK, eds. World Health Organization Classification of Tumors: Pathology and Genetics of Tumors of the Nervous System. Lyon, France: IARC Press; 2000:164-6.

2. Walker AE, Robins M, Weinfeld FD. Epidemiology of brain tumors: the national survey of intracranial neoplasms. Neurology. 1985;35:219-26.

3. Pećina-Šlaus N. Loss of heterozygosity of the APC gene in a case of vestibular schwannoma assessed by two intragenetic markers. Acta Clin Croat. 2012;51(4):643-7.
4. Antinheimo J, Sankila R, Carpén O, Pukkala E, Sainio M, Jäskeläinen J. Population-based analysis of sporadic and type 2 neurofibromatosis-associated meningiomas and schwannomas. Neurology. 2000;54(1):71-6.

5. National Institutes of Health Consensus Development Conference Statement on Neurofibromatosis. Arch Neurol. 1987;45:575-8.

6. Evans DG, Huson SM, Donnai D, Neary W, Blair V, Newton $\mathrm{V}$, et al. A genetic study of type 2 neurofibromatosis in the United Kingdom. II. Guidelines for genetic counselling. J Med Genet. 1992;29:847-52.

7. MacCollin M, Chiocca EA, Evans DG, Friedman JM, Horvitz $\mathrm{R}$, Jaramillo D, et al. Diagnostic criteria for schwannomatosis. Neurology. 2005;64(11):1838-45.

8. Kambe A, Kamitani H, Watanabe T, Oka A, Inagaki H, Ishii T, et al. A non-NF2 case of schwannomas of vestibular and trigeminal nerves with different genetic alterations of NF2 gene: case report. Surg Neurol. 2005;63(1):62-5.

9. Aghi M, Kluwe L, Webster MT, Jacoby LB, Barker FG $2^{\text {nd }}$, Ojemann RG, et al. Unilateral vestibular schwannoma with other neurofibromatosis type 2-related tumors: clinical and molecular study of a unique phenotype. J Neurosurg. 2006;104(2):201-7.

10. Peker S, Bayrakli F, Kiliç T, Pamir MN. Gamma-knife radiosurgery in the treatment of trigeminal schwannomas. Acta Neurochir (Wien). 2007;149(11):1133-7.

11. Bir SC, Ambekar S, Bollam P, Nanda A. Long-term outcome of gamma knife radiosurgery for vestibular schwannoma. J Neurol Surg B Skull Base. 2014;75(4):273-8. doi: 10.1055/s-0034-1371525.

Sažetak

\section{MULTIPLI INTRAKRANIJSKI ŠVANOMI: PRIKAZ SLUČAJA}

\section{Mihalj, K. Dolic, P. Jurinović, N. Ivica Miše, M. Titlić i I. Pintarić}

Švanomi su dobroćudni inkapsulirani tumori koji potječu iz ovojnica perifernih živaca. Najčešće se javljaju kao pojedinačni sporo rastući tumori koji mogu uzrokovati neurološke deficite. Mnogostruki švanomi su iznimno rijetki u bolesnika koji nemaju neurofibromatozu tip 2. Prikazujemo slučaj 60-godišnje bolesnice s negativnom obiteljskom anamnezom za neurofibromatozu ili švanomatozu, koja se prezentirala s neuralgijom trigeminusa i progresivnom paralizom facijalnog živca. Magnetska rezonanca prikazala je prisutnost akustičnog švanoma sa zahvaćanjem i facijalnog živca te švanoma cisternalnog dijela trigeminalnog živca sa širenjem u područje gangliona istog (Meckelova šupljina). Nakon "gamma knife" radiokirurgije simptomi trigeminalne neuralgije su se u potpunosti povukli uz značajno kliničko poboljšanje paralize facijalnog živca.

Ključne riječi: Neurilemom - dijagnostika; Neurilemom - kirurgija; Neurom, akustični - dijagnostika; Neurom, akustični kirurgija; Trigeminalni živac, bolesti - kirurgija; Prikazi slučaja 